in India, Kenya, Palestine, and Cyprus, has been appointed Development Commissioner in Uganda.

\title{
South African Native Affairs
}

THE Union Native Affairs Department, a government within a government, has under its care a population of more than 7 million souls-more than two-thirds of the total inhabitants of the country. It carries a heavy burden of responsibility and is freely criticized from two quarters: by those who think it does too much and by those who think it does too little. It is, in fact, more liberal in its administration than Parliament is in its legislation. The Social and Economic Planning Council, in its Report (No. 9) on the Native Reserves, judiciously sums up the Department's achievements in the reserves:

'Apart from the minimum requirements of maintaining peace and order, which, on the whole, has been well done, it has in recent years become more definitely a welfare department; it has made serious efforts to improve Native agriculture and to encourage markets; it has co-operated willingly and effectively in the extension of educational facilities in the Reserves; it has taken a growing interest in social welfare projects in these areas. In its hands has lain the heavy task of adjusting progressive and modern conceptions of government to the traditional tribal mores-a delicate and difficult task.'

The Department's activities are by no means limited to the reserves, for more than half the native population lives outside the Native Areas, and there its task becomes more complicated and vexatious year by year. The Department spends about $f_{3}$ millions voted by Parliament and administers the Trust Fund for the purchase of additional lands for the Africans: in ten years this amounted to $\ell_{7}$ millions. It is no longer responsible for Native education, since this has now become a charge upon the Consolidated Revenue Fund of the Union and is administered by the Education departments: the expenditure has risen steadily from $£ 605,509$ in $1934-5$ to $£ 3,858,000$ in $1947-8$. But the Department runs its own agricultural colleges and makes a grant of $f_{1} 6,000$ annually to the Fort Hare Native College. It is not directly responsible for health, for which there is a separate department; but it grants $£ 80,000$ a year to Mission hospitals and for the training of Native nurses. It spends $f_{1,235,000}$ a year on Old Age and Blind pensions, invalidity grants, and poor-relief. 'It should be noted ', says Dr. D. L. Smit, Deputy Chairman of the Native Affairs Commission, in the first report issued since the conclusion of the war, 'that in no other State in Africa has the full medical course been provided for African students and that in education and social services the Union of South Africa is ahead of any of the northern territories.'

Perhaps only one who, like the present writer, has recently travelled by car 6,000 miles through the Native Areas, can read with understanding and appreciation the voluminous Report of the Native Affairs Department, the Report of the Native Affairs Commission, and the Report of the Social and Economic Planning Council. His tour left three impressions on the mind of the writer: $(a)$ the high quality of the Department's officers; $(b)$ the amazing extent and variety of the work they are doing; and $(c)$ the tremendous task that lies before them. This last point is mainly the subject of the Planning Council's Report. They find, what must be evident to every observer, that the Reserves are rapidly deteriorating, that, in spite of $a$ high mortality rate, the population of the Reserves is increasing at a faster rate than the Reserves can support under existing conditions; and that the Reserves are overstocked. The situation, they say, calls for drastic measures. In these Notes for October 1945 we referred to the Union Government's Twelve Year Plan. Under this scheme, for which Parliament voted fro millions, local planning committees have been at work (the writer met one of them in the Transkei and one in Zululand) and betterment plans have been put in operation. Now the Planning Council proposes to change the constitution of these committees and establish Regional Development Authorities. They advocate the setting up of 
a Research Institute where the fundamental problems relating to land use in the widest aspects can be investigated. They ask for reform in education to bring it into closer association with everyday life. And they wish for the addition of economists and sociologists as advisers on the staff of the Native Affairs Department.

The Council sees clearly that the time has passed when all Natives could have their own bits of land. To say nothing of those who live outside, there are now large numbers of landless people in the Reserves. The redundant Africans must be drafted to, and trained for, industry whether in the Reserves or outside. Both the Council and the Native Affairs Commission strongly condemn the present system of migratory labour: it is morally, socially, and economically wrong, say the Council. 'The whole substance of rural life is being undermined by interference with family life due to the absence of large numbers of the males at industrial centres, and the consequent drift of their families to undesirable surroundings in the towns', say the Commission. 'This absence of family discipline, with all its consequences, is an evil that presents one of the most serious problems which the Government has to face, and in all future developments earnest attention should be given to the setting aside of areas where permanent homes may be provided for industrialized Natives, and their families, within easy reach of their work.' 'This implies the building of Native townships, as, indeed, is being done in many places. Territorial segregation (or separation) is a thing of the past (if it ever existed or could have existed); residential segregation has come to stay.

\section{Research in South Africa}

THE South African Council for Educational, Sociological, and Humanistic Research has set aside funds not to exceed $f_{12}$,000 for financing two extensive surveys in sample areas of African life, one urban and one rural. The urban area to be investigated is the Atteridgeville Location, Pretoria, a Native township of about 1,350 houses built by white labour; and the data to be collected comprise the composition and origin of the population; social organization; economic conditions; social welfare; religion; housing and other facilities; crime and delinquency; health and health services; inter-racial attitudes; nutrition; and the educational system. Four experts (economist, sociologist, educationalist, doctor) on a full- or part-time basis, and four non-European field workers with clerical assistants, are to be engaged on this research for about a year; and it is suggested that assistance be obtained from the Universities of Witwaterstand and Pretoria and other agencies. For the rural survey the Victoria East district of the Ciskei has been chosen; it presents one of the most difficult problems in all the Union. The area and its physical conditions; soil and crops; the population; economic conditions; health and nutrition; social organization and education; all these are to be studied especially in view of the rehabilitation plans of the Native Affairs Department. The same number of experts and non-European field-workers are to be employed as for the urban survey-a sociologist, an economist, a soil expert, an expert of livestock and crops; and assistance is expected from Rhodes University College, Grahamstown; Fort Hare; and Fort Cox Agricultural College.

Assisted by a grant from the Rockefeller Foundation, the South African Institute of International Affairs appointed a full-time Research Secretary in June I947 and embarked upon the investigation of three subjects: (a) Land tenure in Africa south of the Sahara; (b) The High Commission Territories; and (c) Transport and Communications in southern Africa. Miss Helen Scroggie is engaged upon the first of these projects; she will estimate the effect of different types of European control and native policy upon different types of indigenous land system. Sir Charles Dundas, a former Governor of Uganda, is preparing one section of a book on the historical, political, and constitutional aspects of the High Commission Territories; and Dr. Hugh Ashton will deal with their ethnography. A third section, on the 